\title{
Biosynthesis and Functionalization of Bacterial Cellulose Membranes with Cerium Nitrate and Silver Nanoparticles
}

\author{
Stéfani Regina Zibetti Teixeira ${ }^{a}$, Emily Marques dos Reis ${ }^{c}$, Giannini Pasiznick Apati ${ }^{a}$, Marcia Margarete Meierd, \\ André Lourenço Nogueira ${ }^{a, b}{ }^{\circledR}$, Michele Cristina Formolo Garcia ${ }^{a}{ }^{\circledR}$, Andrea Lima dos Santos Schneidera, \\ Ana Paula Testa Pezzin ${ }^{a, b *}$, Luismar Marques Porto ${ }^{c}$
}

${ }^{a}$ Departamento de Engenharia Química, Universidade da Região de Joinville, Campus Universitário, Zona Industrial, 89219 710, Joinville, SC, Brasil

${ }^{b}$ Programa de Mestrado em Engenharia de Processos, Universidade da Região de Joinville UNIVILLE, Paulo Malschitzki, 10, Campus Universitário, Zona Industrial, 89219 710, Joinville, SC, Brasil

'Programa de Pós-Graduação em Engenharia Química - PósENQ, Universidade Federal de Santa Catarina - UFSC, Campus Universitário, Trindade, 88040-900 Florianópolis, SC, Brasil ¿Programa de Pós-Graduação em Química Tecnológica, Universidade do Estado de Santa Catarina UDESC,Campus Universitário, Zona Industrial, 89219 710, Joinville, SC, Brasil

Received: January 20, 2019; Revised: August 29, 2019; Accepted: September 29, 2019

This work aimed to synthesize bacterial cellulose (BC) membranes functionalized with $\mathrm{Ce}\left(\mathrm{NO}_{3}\right)_{3}$ and silver nanoparticles (AgNPs) heat-treated in oven and autoclave. The AgNPs were characterized by TEM and the membranes were characterized by their rehydration capacity, Thermogravimetric Analysis (TGA), Scanning Electron Microscopy with Dispersive Energy Spectroscopy (SEM/EDS), Wide-angle X-ray Diffractometry (XRD), Atomic Absorption Spectroscopy (AAS), antimicrobial activity and cytotoxicity. The $\mathrm{BC}$ membranes were white to light yellow or brown indicating functionalization with AgNps with $20 \mathrm{~nm}$. XRD detected a decrease in the degree of crystallinity in functionalized membranes. The autoclaved samples exhibited the largest porosity and good rehydration capacity. AAS showed Ag presence in all samples. The best antibacterial activity was achieved for the membrane's oven treated with $40 \mathrm{ppm}$ of AgNPs. Among the functionalized membranes, the most recommended to be used as burn dressing is the $\mathrm{Ag} 40 \mathrm{~A}$ and $\mathrm{Ag} 20 \mathrm{CN} 1.1 \mathrm{~A}$ since they showed good porosity, good antimicrobial activity, and better suitable cell viability.

Keywords: bacterial cellulose, silver nanoparticles, cerium nitrate, burn dressings.

\section{Introduction}

Accidents with burns have become a global public health problem. When the burn is not fatal, it causes deconfiguration, prolonged hospitalization and/or disability of the patient ${ }^{1}$. Hospital infections are among the most important side effects and have the potential to cause serious complications. Burn wounds provide an ideal medium for bacterial proliferation and an entry portal into the bloodstream. The loss of the epithelial barrier, hypermetabolic/hypercatabolic states, and immunosuppression predispose burned patients to infections ${ }^{2}$. During the last decade, bacterial cellulose (BC) has attracted great attention for its wide range of biomedical and tissue engineering applications ${ }^{3}$. It can be used as a temporary skin substitute in the treatment of difficult wounds, burns and ulcers or as durable support required for tissue engineering. $\mathrm{BC}$ consists of a translucent and gelatinous film, formed by cellulose nano and microfibrils and as such $\mathrm{BC}$ is one of three nanoscale-sized, that can be produced by several microorganisms, such as Komagataeibacter, Agrobacterium, Rhizobium, Sarcin, Alcaligenes. The chemical structure of

*e-mail: anapezzin@yahoo.com.br.
$\mathrm{BC}$ is composed of (1-4) D-glucopyranose chains with $\beta$-type glycosidic bonds ${ }^{4}$. The physical and mechanical properties of $\mathrm{BC}$ membranes are related to their well-spaced nano and microfibrils, thus creating an extensive surface area with spacings that allow the retainment of a large amount of liquid, while maintaining a high degree of order. The hydrogen bonds between these fibrous units stabilize their structure and offer a high mechanical resistance ${ }^{5}$. Based on its recent tested clinical performance, and in accordance with several other studies ${ }^{4,6}$ on the properties of this biomaterial, BC can be considered an ideal material for high quality dressings ${ }^{6}$. However, BC itself has no antibacterial activity to prevent wound infection. In this sense, great efforts have been devoted to the development of antibacterial $\mathrm{BC}$ membranes, especially those containing silver nanoparticles (AgNPs) ${ }^{7}$. Silver and its compounds have known antibacterial and antifungal activity. Yet, at the nanoscale, this action is amplified ${ }^{8}$. According to Li et al. ${ }^{9}$, thermic treatment of silver, besides aiding in the functionalization, can induce the growth of AgNPs, that is, silver in the form of nanoparticles. Cerium is a metal with bacteriostatic properties and is effective in the form of cerium nitrate $\left(\mathrm{Ce}\left(\mathrm{NO}_{3}\right)_{3}\right)$ against a wide range of bacteria. It has 
potent antimicrobial action and low toxicity to mammalian cells. It is believed that cerium nitrate exerts a protective effect against post-burn immunosuppression caused by lipidprotein complexes ${ }^{10}$. In this context, this work proposes the synthesis of $\mathrm{BC}$ membranes with different concentrations of $\mathrm{Ce}\left(\mathrm{NO}_{3}\right)_{3}$ and AgNPs, submitting them to different thermal treatments, and characterization techniques (physical-chemical, thermal, antibacterial activity and cytotoxicity).

\section{Methodology}

The process of synthesis and characterization of functionalized $\mathrm{BC}$ membranes submitted to different heat treatments can be more clearly described in the schematic illustration shown in Figure 1.

\subsection{Synthesis and purification of BC membranes}

The microorganism used was the bacterium Komagataeibacter hanseni ATCC 23769, preserved in a refrigerator. For its activation and cultivation, mannitol medium (MM) was used, containing $\mathrm{C}_{6} \mathrm{H}_{14} \mathrm{O}_{6}\left(20 \mathrm{~g} \cdot \mathrm{L}^{-1}\right)$, soy peptone $\left(5 \mathrm{~g} \cdot \mathrm{L}^{-1}\right)$, yeast extract $\left(5 \mathrm{~g} \cdot \mathrm{L}^{-1}\right), \mathrm{Na}_{2} \mathrm{HPO}_{4}\left(2.7 \mathrm{~g} \cdot \mathrm{L}^{-1}\right)$ and $\mathrm{C}_{6} \mathrm{H}_{8} \mathrm{O}_{7}\left(1.15 \mathrm{~g} \cdot \mathrm{L}^{-1}\right)$, autoclaved at $121{ }^{\circ} \mathrm{C}$ for $20 \mathrm{~min}$. The cells were activated in $500 \mathrm{~mL}$ Erlenmeyer flasks containing $100 \mathrm{~mL}$ of MM, incubated at $30^{\circ} \mathrm{C}$ under static conditions for 2 days. After this time, the inoculum was transferred to the culture medium at a ratio of $20 \%$ with optical density (O.D.) between 0.15 and 0.19 . This step was carried out in $250 \mathrm{~mL}$ Erlenmeyer flasks with $50 \mathrm{~mL}$ of culture medium and/or in 96-well plates with $200 \mu \mathrm{L}$ of culture medium, both incubated in an oven at $30^{\circ} \mathrm{C}$ under static condition for 12 days for the formation of hydrated BC. The synthesized BC was separated from the culture liquid, washed with distilled water, and purified with a $0.1 \mathrm{M} \mathrm{NaOH}$ solution at $80^{\circ} \mathrm{C}$ for $60 \mathrm{~min}$ to remove the bacterial cells and other impurities. Then, the pellicles were washed with distilled water until reached a of $\mathrm{pH} 7$, and sterilized at $121^{\circ} \mathrm{C}$ for $15 \mathrm{~min}$.

\subsection{Functionalization of $B C$ membranes}

The solution containing 40 ppm of AgNPs was purchased from Diver Saúde, Curitiba, Brazil. $\mathrm{Ce}\left(\mathrm{NO}_{3}\right)_{3}$ also purchased from Neon, São Paulo, Brazil as $\mathrm{Ce}\left(\mathrm{NO}_{3}\right)_{3} \cdot 6 \mathrm{H}_{2} \mathrm{O}, 99 \%$ A.P. The solutions containing $\mathrm{Ce}\left(\mathrm{NO}_{3}\right)_{3}$ and $\mathrm{AgNPs}$ were functionalized into $\mathrm{BC}$ membranes in different concentrations, based on the commercial drug formulation Dermacerium ${ }^{\circledR}$ (Table 1). The membranes were manually pressed with absorbent paper to remove excess of water to enhance the absorption of the AgNPs and $\mathrm{Ce}\left(\mathrm{NO}_{3}\right)_{3}$ after immersion in the respective solutions for $24 \mathrm{~h}$, rotating every two hours to ensure the total absorption of the substances by the membranes ${ }^{11}$. The membranes were then submitted to two different thermal treatments, aiming to establish the functionalization between the $\mathrm{Ag}$ and the $\mathrm{BC}$ hydroxyls ${ }^{11}$. The first one was performed in an oven at $120^{\circ} \mathrm{C}(\mathrm{O})$ and the second one in an autoclave at $121{ }^{\circ} \mathrm{C}(\mathrm{A})$, both for two hours.

\subsection{Lyophilization of $B C$}

The membranes were lyophilized to remove all water without collapsing the pores. The membranes were previously frozen and dehydrated by the lyophilization process using Terroni LT 1000 Lyophilizer for $24 \mathrm{~h}$ and stored in a desiccator for further characterization analyses.

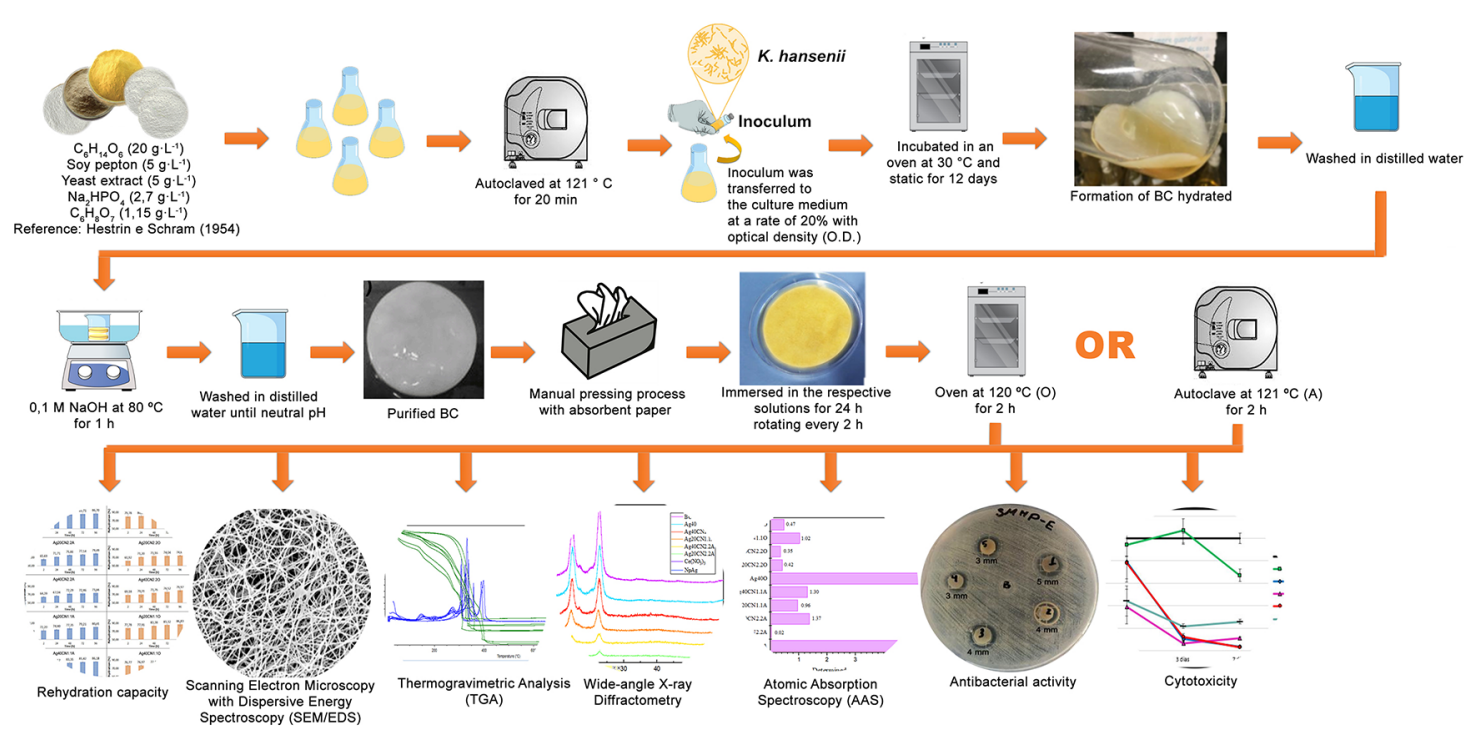

Figure 1. Schematic illustration of the synthesis of functionalized $\mathrm{BC}$ membranes submitted to different thermal treatments and characterization of the membranes obtained. 
Table 1. Concentrations of $\mathrm{Ce}\left(\mathrm{NO}_{3}\right)_{3}$ and $\mathrm{AgNps}$ in the functionalized $\mathrm{BC}$ membranes with the thermal treatments performed and symbology of the samples.

\begin{tabular}{|c|c|c|}
\hline Biomaterial composition & Autoclave thermal treatment & Oven thermal treatment \\
\hline $\mathrm{BC}$ & - & - \\
\hline $\mathrm{BC}+\mathrm{AgNps} 40 \mathrm{ppm}$ & $\mathrm{Ag} 40 \mathrm{~A}$ & $\mathrm{Ag} 40 \mathrm{O}$ \\
\hline $\mathrm{BC}+\mathrm{AgNps} 20 \mathrm{ppm}+\mathrm{Ce}\left(\mathrm{NO}_{3}\right)_{3} 2.2 \%$ & $\mathrm{Ag} 20 \mathrm{CN} 2.2 \mathrm{~A}$ & $\mathrm{Ag} 20 \mathrm{CN} 2.2 \mathrm{O}$ \\
\hline $\mathrm{BC}+\mathrm{AgNps} 40 \mathrm{ppm}+\mathrm{Ce}\left(\mathrm{NO}_{3}\right)_{3} 2.2 \%$ & $\mathrm{Ag} 40 \mathrm{CN} 2.2 \mathrm{~A}$ & $\mathrm{Ag} 40 \mathrm{CN} 2.2 \mathrm{O}$ \\
\hline $\mathrm{BC}+\mathrm{AgNps} 20 \mathrm{ppm}+\mathrm{Ce}\left(\mathrm{NO}_{3}\right)_{3} \quad 1.1 \%$ & $\mathrm{Ag} 20 \mathrm{CN} 1.1 \mathrm{~A}$ & $\mathrm{Ag} 20 \mathrm{CN} 1.1 \mathrm{O}$ \\
\hline $\mathrm{BC}+\mathrm{AgNps} 40 \mathrm{ppm}+\mathrm{Ce}\left(\mathrm{NO}_{3}\right)_{3} \quad 1.1 \%$ & $\mathrm{Ag} 40 \mathrm{CN} 1.1 \mathrm{~A}$ & $\mathrm{Ag} 40 \mathrm{CN} 1.1 \mathrm{O}$ \\
\hline
\end{tabular}

\subsection{Characterization of AgNPs}

\subsubsection{Transmission Electron Microscopy (TEM)}

TEM analysis (FEI Tecnai $G^{2}$ F20, equipped with EDS system) of AgNPs was performed by using two drops of the concentrated colloidal dispersions, which were carefully dripped over copper grids (300 mesh) coated with carbon. The grids were dried overnight at room conditions before being analyzed by the microscope operating at $200 \mathrm{kV}$. The software ImageJ (public domain). The software ImageJ was used to evaluate the images and determine the particle size.

\subsection{Characterization of $B C$ membranes}

\subsubsection{Rehydration capacity}

The membranes were lyophilized and weighed to obtain the dried mass (dm). Then, the membranes were immersed in $200 \mathrm{~mL}$ of deionized water and kept at room temperature up to $96 \mathrm{~h}$. The mass of the rehydrated BC ( $\mathrm{rm}$ ) was determined after 2, 24, 48, 72 and $96 \mathrm{~h}$. Before weighing, the excess water was drained for 60 seconds. The water reabsorption capacity was obtained by equation $1^{12}$.

$$
\text { Rehydration capacity }=\frac{r m-d m}{r m} .100
$$

\subsubsection{Thermogravimetric analysis (TGA)}

TGA analyses were performed to determine the thermal degradation behavior (thermal stability), mass loss, based on the onset temperature for degradation $\left(\mathrm{T}_{\text {onset }}\right)$ and the maximum degradation temperature $\left(\mathrm{T}_{\max }\right)$ of the membranes. TG curves were obtained using the equipment TGA-Q50 (TA Instruments). Samples were heated from 25 to $1000^{\circ} \mathrm{C}$ at a heating rate of $10^{\circ} \mathrm{C} \mathrm{min}-1$ under an oxidizing atmosphere.

\subsubsection{Scanning electron microscopy with dispersive energy spectroscopy (SEM/EDS)}

Scanning electron microscope JEOL (model JSM-6390LV) was used to acquire the images of membrane surfaces to evaluate their microstructural characteristics. Samples were fixed on metal supports and covered with thin gold layer. Electron beam and X-rays were emitted toward the samples and the reflected signals were detected by a solid-state silicon detector for a point elemental analysis.

\subsubsection{Wide-angle X-ray diffractometry (DRX)}

$\mathrm{X}$-ray diffraction was measured with an X-ray diffractometer (Model XRD8 Advance, Bruker AXS). The diffractograms were recorded using $\mathrm{CuK}-\mathrm{a}$ radiation $(\mathrm{k}=1.5418 \AA), 40 \mathrm{kV}$ and $25 \mathrm{~mA}=1000 \mathrm{~W}$. Samples were scanned from 5 to $60^{\circ}$ at a scan speed of $1^{\circ} / \mathrm{min}$. The $\mathrm{X}^{\prime}$ Pert HighScore Plus software was used to analyze the diffractograms and determine the crystallinity degree $(\mathrm{Xc})$ of the membranes. The Xc was determined as a function of the areas corresponding to the crystalline peaks and the amorphous halo (peak extended under the crystalline peaks) ${ }^{13}$ by equation 2 :

$$
X c=\frac{A c}{A c+A a} .100
$$

where Ac represents the sum of the areas of the crystalline peaks and Aa corresponds to the area of the amorphous halo.

\subsubsection{Atomic absorption spectroscopy $(A A S)$}

The amount of Ag contained in the functionalized BC membranes was quantified by AAS using the equipment Varian model 55B SpectrAA. Samples were previously dried in an oven at $105^{\circ} \mathrm{C}$ for $2 \mathrm{~h}$. The mass of each sample was determined in an analytical balance, and the samples were digested with $10 \mathrm{~mL}$ of $50 \%(\mathrm{v} / \mathrm{v}) \mathrm{HNO}_{3}$ in a digestor block for $2 \mathrm{~h}$ at $105^{\circ} \mathrm{C}$. After the digestion process, the samples were cooled to room temperature, and centrifuged at $3500 \mathrm{rpm}$ for $20 \mathrm{~min}$ for phase separation. Then, the supernatant was collected and the Ag content in the samples was measured in an AAS at wavelength $\lambda=328.1 \mathrm{~nm}$, specific for Ag. Dilutions with $\mathrm{HNO}_{3} 50 \% \mathrm{v} / \mathrm{v}$ were necessary for the samples that extrapolated the reading ranges. After measuring the silver content in the solutions, the obtained values were divided by the individual mass of the samples, and the results were presented in $\mathrm{mg} / \mathrm{g}$.

\subsubsection{Antibacterial activity}

The antibacterial activity of the BC membranes was assessed using the disc diffusion technique of Kirby and Bauer $^{14}$. The bacteria Pseudomonas aeruginosa (Gram- 
negative) and Staphylococcus aureus (Gram-positive) were used in the assays. These bacteria were pre-cultured for $24 \mathrm{~h}$ at $37^{\circ} \mathrm{C}$, in trypticasein soybean broth (TSB). The microorganisms tested were diluted with $0.9 \%$ of a sterile saline solution to achieve a concentration of about 0.5 of the McFarland standard. Thereafter, the bacteria suspension was evenly distributed on Petri dishes with Müller Hilton (MH) medium using a swab to form a layer of microorganisms. The neat and functionalized $\mathrm{BC}$ membranes were cut into $6 \mathrm{~mm}$ diameter discs and placed over the bacterial growth media. The inhibition zone test was used to evaluate the antimicrobial activity ${ }^{15}$.

\subsubsection{Cytotoxicity}

Mouse fibroblasts (L929 strain), multiplied in Dulbecco's Modified Eagle Medium (DMEM, supplemented with 15\% fetal bovine serum) were used to evaluate the cytotoxicity of the pure and functionalized BC membranes. The biomaterials were autoclaved and placed in DMEM medium for $24 \mathrm{~h}$.

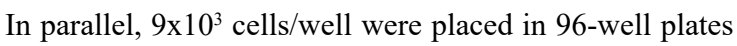
and incubated for $24 \mathrm{~h}$ at $37^{\circ} \mathrm{C} / 5 \% \mathrm{CO}_{2}$. After that, metal solutions were poured over the adhered cells, and incubated again at $37^{\circ} \mathrm{C} / 5 \% \mathrm{CO}_{2}$ for 1,3 and 7 days. The membranes were then removed, and cells were washed with phosphate buffered saline (PBS) to remove dead or non-adherent cells. Cytotoxicity test was performed by the MTS method ${ }^{16}$. The optical density reading was performed in the plate reader at $490 \mathrm{~nm}$ to calculate the relative cell viability.

\subsubsection{Statistical analysis}

The antibacterial and cytotoxicity assays were performed in triplicate, and statistical analysis was performed using one-way ANOVA followed by the Tukey test for multiple comparisons, with 95\% confidence. The analyses were performed using the Minitab17 software.

\section{Results and Discussion}

\subsection{Characterization of AgNPs}

\subsubsection{Transmission electron microscopy (TEM)}

In this study, TEM was applied to determine the particle size of the AgNPs, as shown in the images displayed in Figure 2. Particles with an average size of $20 \mathrm{~nm}$ were observed, as well as the presence of some agglomerates. EDS analysis of a single particle showed a predominance of $\mathrm{Ag}$, as expected. The presence of $\mathrm{Cu}$ in the analysis might be due to the grid, while the $\mathrm{Cl}$ and $\mathrm{Si}$ might be attributed to some compounds added to the formulation used by the company (Diver Saúde) to synthesize the colloidal silver.

\subsection{Characterization of $B C$ membranes}

As shown in Figure 3, macroscopically homogeneous membranes were obtained with colours ranging from white, for the pure BC, to brownish for the membranes containing AgNPs and $\mathrm{Ce}\left(\mathrm{NO}_{3}\right)_{3}$. Darker shades were visualized by increasing the concentration of AgNPs. Color changes in a depended fashion with the concentration of $\mathrm{AgNP}$ and $\mathrm{Ce}\left(\mathrm{NO}_{3}\right)_{3}$ and are a visual indication that the antibacterial substances were incorporated into the membranes. Li et al. ${ }^{9}$ used UV-Visible absorption to correlate the concentration of AgNPs with the variation in coloration from bright yellow to deep yellow as well as to brown.

\subsubsection{Rehydration capacity}

From Figure 4, it is possible to observe that the neat BC membrane reabsorbed $97.17 \%$ of water in the first $2 \mathrm{~h}$ of test, presenting slightly increase over time. These results demonstrate the efficiency of such membrane as wound dressing absorber. According to the Biocel user's manual, BC curatives may be kept sterile and dry. When applied, they should be hydrated to better adhere to the lesion, facilitating skin's suitability.

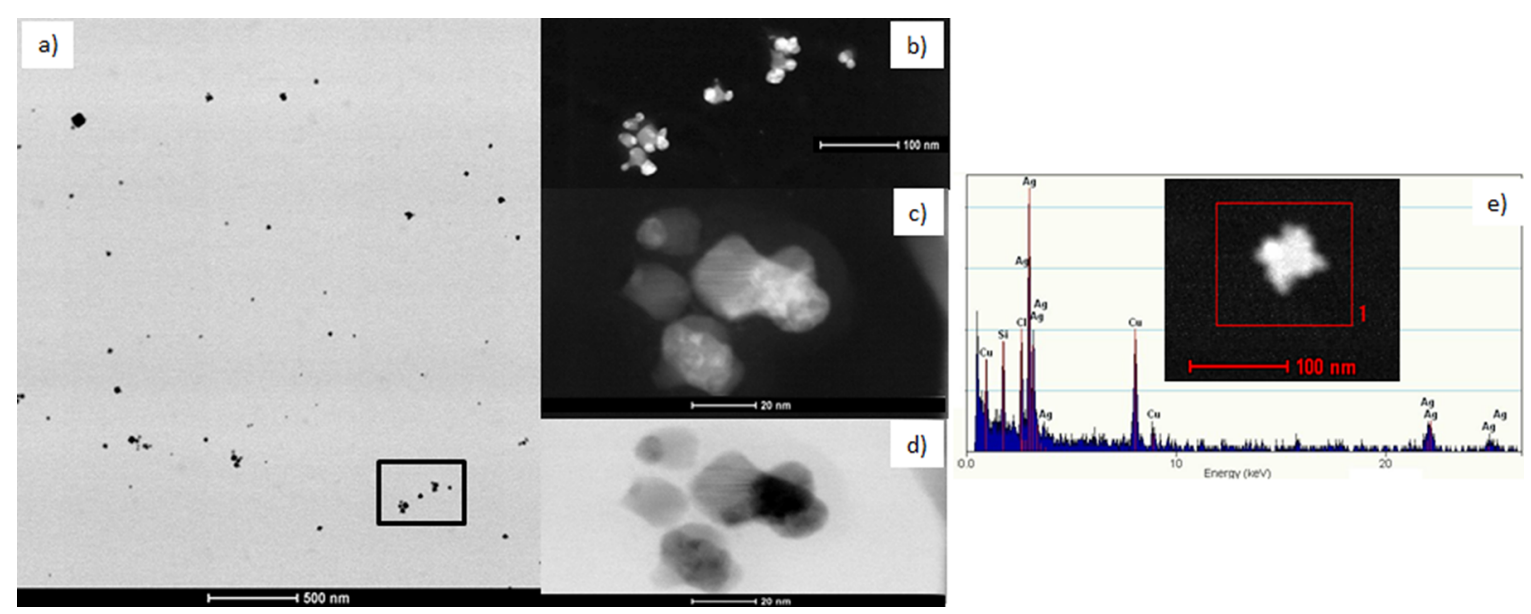

Figure 2. TEM images of AgNPs with different magnifications and contrasts (a, b, c, d); EDS analysis of a single silver nanoparticle (e). 


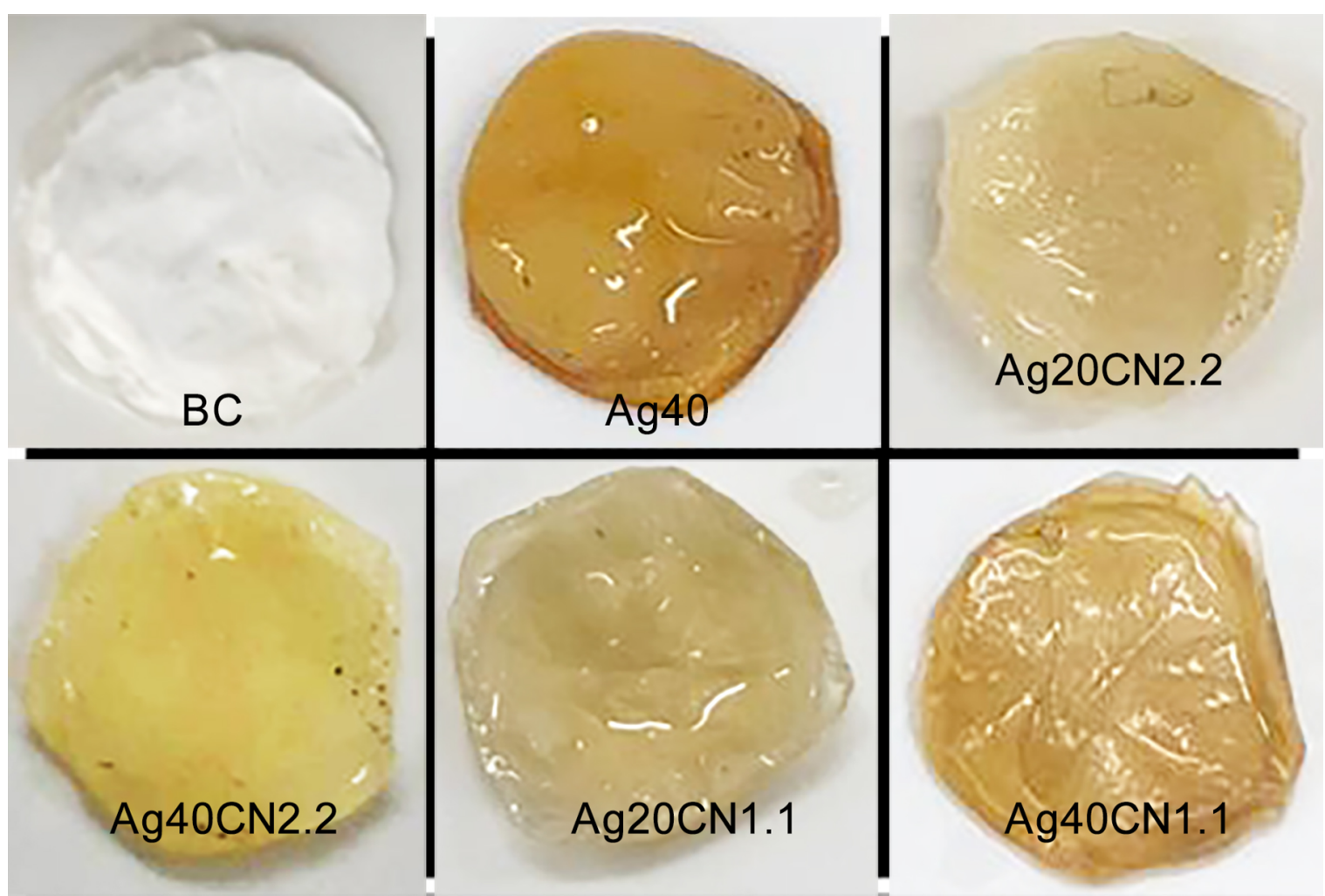

Figure 3. Photographs of the pure $\mathrm{BC}$ and the functionalized membranes with $\mathrm{Ce}(\mathrm{NO} 3) 3$ and $\mathrm{AgNPs}$.

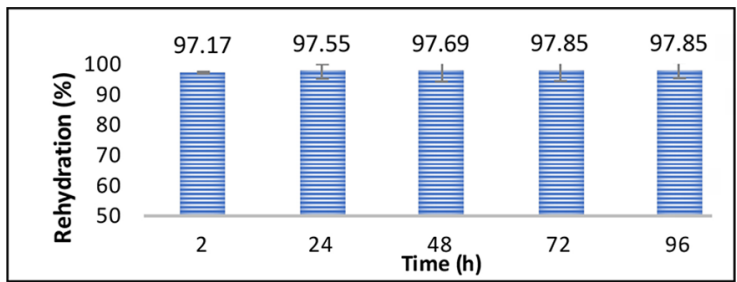

Figure 4. Rehydration capacity (\%) of neat BC membrane over time.

The rehydration capacity of the functionalized membranes decreased in comparison with the neat BC (Fig. 5). These results suggest that the antibacterial compounds (AgNPs and $\left.\mathrm{Ce}\left(\mathrm{NO}_{3}\right)_{3}\right)$ might have been incorporated in the membranes through their attachment to the hydroxyl groups of BC. Based on this hypothesis, the membrane should have fewer free hydroxyls than the neat $\mathrm{BC}$, reducing its affinity with water. In other words, the presence of AgNPs or $\mathrm{Ce}\left(\mathrm{NO}_{3}\right)_{3}$ in the membranes contributed to the reduction of hydrogen bonds between the water and the $\mathrm{OH}$ groups, decreasing the space available for the water diffusivity toward the core of the membranes. Molina et al. ${ }^{17}$ reported that any factor that reduces the pore size of the $\mathrm{BC}$ membrane will have a direct effect on the transport mechanism in the hydrogel. The thermal treatment can collapse the pores of the membranes, hindering the rehydration of the $\mathrm{BC}$ membranes. Thus, the findings obtained in this study suggest that the rehydration behavior of the $\mathrm{BC}$ membranes might be influenced by the volume occupied by the AgNPs and $\mathrm{Ce}\left(\mathrm{NO}_{3}\right)_{3}$ inside the pores. The membrane submitted to the thermal treatment in an oven in the presence of only AgNPs showed a slightly slower water absorption rate in the first $48 \mathrm{~h}$. However, the final rehydration capacity was basically the same for samples Ag40A and Ag40O after $96 \mathrm{~h}$. In general, the functionalized $\mathrm{BC}$ membranes prepared with the highest concentrations of $\mathrm{Ce}\left(\mathrm{NO}_{3}\right)_{3}(\mathrm{Ag} 20 \mathrm{CN} 2.2$ and $\mathrm{Ag} 40 \mathrm{CN} 2.2)$ showed a lower rehydration capacity when compared to the neat $\mathrm{BC}$ and $\mathrm{Ag} 40$ samples. These results suggest that the presence of $\mathrm{Ce}\left(\mathrm{NO}_{3}\right)_{3}$ in $\mathrm{BC}$ membranes contributed for the reducing of the pore sizes or even clogging them, reducing the pathways for water absorption. This hypothesis is supported by comparing the rehydration capacity of the samples containing 2.2 and $1.1 \%$ of $\mathrm{Ce}\left(\mathrm{NO}_{3}\right)_{3}$. The results shown in Figure 5 for such samples demonstrate that the water absorption by the membranes increased when the $\mathrm{Ce}\left(\mathrm{NO}_{3}\right)_{3}$ content was lowered. It is important to notice that the membranes submitted to a thermal treatment in the autoclave and in the oven presented a rehydration capacity with opposite behavior by increasing the concentration of AgNPs.

\subsubsection{Thermogravimetric analysis (TGA)}

Figures $6 \mathrm{a}$ and $6 \mathrm{~b}$ show the TG curves for the functionalized $\mathrm{BC}$ membranes submitted to the oven and autoclave thermal treatment, respectively. Temperature data for the beginning 


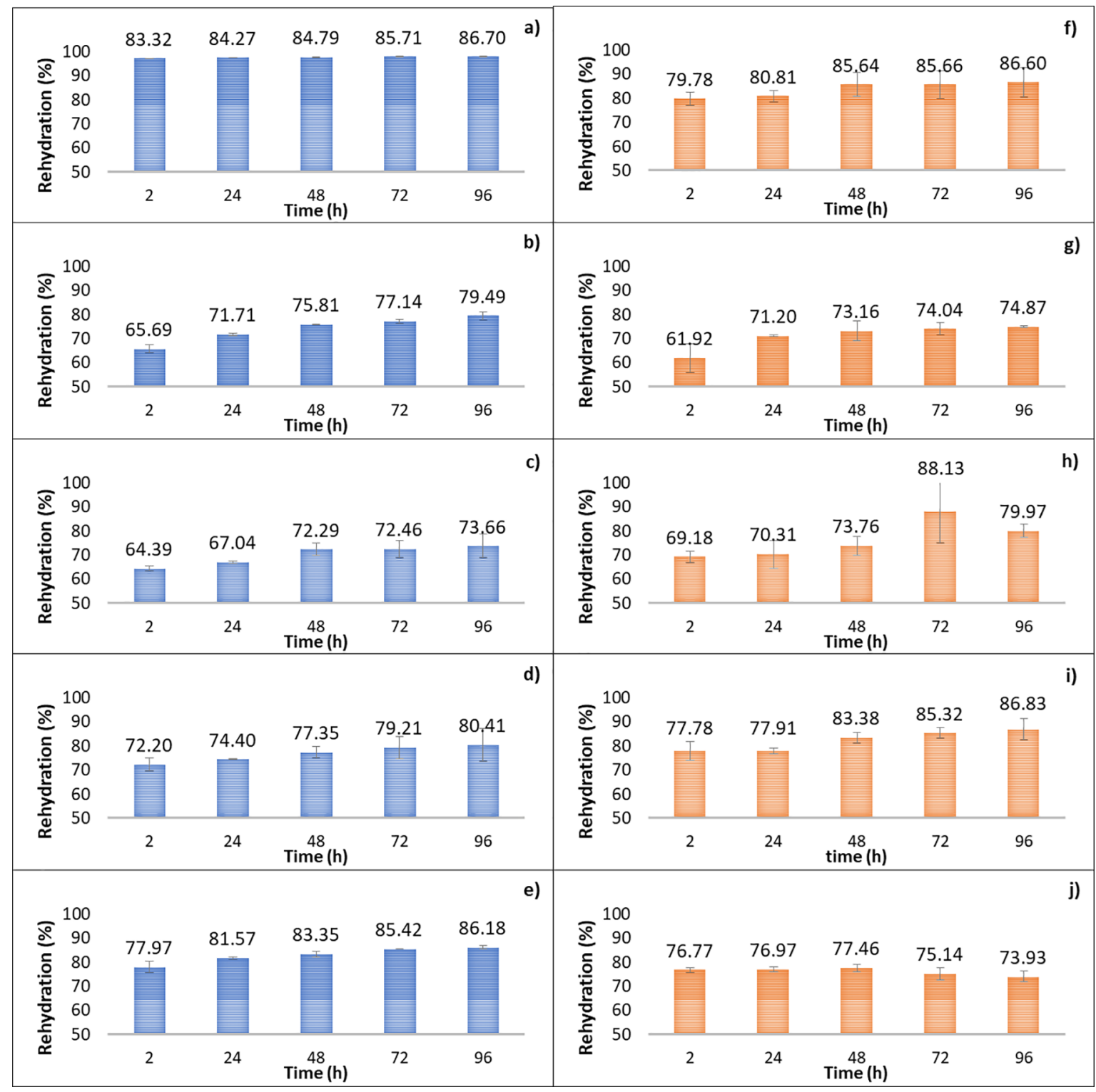

Figure 5. Rehydration capacity (\%) of functionalized BC membranes over time. a) $\mathrm{Ag} 40 \mathrm{~A}, \mathrm{~b}$ ) $\mathrm{Ag} 20 \mathrm{CN} 2.2 \mathrm{~A}, \mathrm{c}) \mathrm{Ag} 40 \mathrm{CN} 2.2 \mathrm{~A}$, d) Ag20CN1.1A, e) Ag40CN1.1A, f) Ag40O, g) Ag20CN2.2O, h) Ag40CN2.2O, i) Ag20CN1.1O, j) Ag40CN1.1O).

of degradation $\left(\mathrm{T}_{\text {onset }}\right)$, maximum degradation temperature $\left(\mathrm{T}_{\text {max }}\right)$, mass losses and residues are shown in Table 2. All BC membranes presented the same characteristic degradation profile with three mass loss events. The first stage of mass loss occurred between room temperature $\left(\cong 30^{\circ} \mathrm{C}\right)$ and $150^{\circ} \mathrm{C}$, referring to the water loss of the samples ${ }^{18}$. The second, and more significant stage, occurred with a $\mathrm{T}_{\text {onset2 }}$ of $284^{\circ} \mathrm{C}$ and a $\mathrm{T}_{\max 2}$ of $301{ }^{\circ} \mathrm{C}$ for neat $\mathrm{BC}$, and is attributed to cellulose degradation ${ }^{18}$. For the functionalized $\mathrm{BC}$ membranes, $\mathrm{T}_{\max 2}$ was determined between $302{ }^{\circ} \mathrm{C}$ and $375^{\circ} \mathrm{C}$. The third stage represents the degradation of carbonaceous residues that can extend from 400 to $600^{\circ} \mathrm{C}^{19}$. This third event was observed in this work in the range between $310^{\circ} \mathrm{C}$ and $491{ }^{\circ} \mathrm{C}$. Considering that the analysis was performed under an oxidizing atmosphere, the residual mass may indicate the presence of inorganic material in the sample ${ }^{7}$, suggesting the incorporation of the metallic elements in the $\mathrm{BC}$ membrane.

It was also possible to observe that in the membranes with a higher concentration of the functionalizing agents, the percentage of residue increased, reinforcing this relation. Another fact also observed was that the highest residual percentages were found for the samples submitted to the thermal treatment in the oven, pointing this as the better functionalization strategy due to the greater amount of residue.

\subsubsection{Scanning electron microscopy with dispersive energy spectroscopy (SEM/EDS)}

Figure 7 shows the image obtained by scanning electron microscopy (SEM) analysis of the upper surface of the neat 

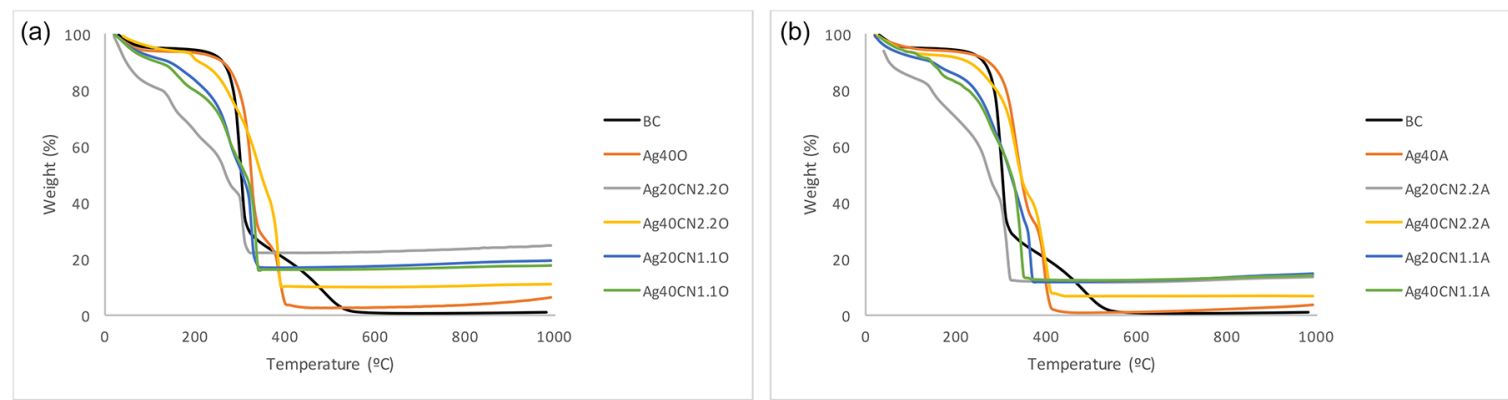

Figure 6. TG curves obtained by thermogravimetric analysis of the $\mathrm{BC}$ membranes submitted to different thermal treatments: a) oven and b) autoclave.

Table 2. Data extracted from TG curves for all BC membranes submitted to different thermal treatments.

\begin{tabular}{|c|c|c|c|c|c|c|c|c|}
\hline Sample & $\begin{array}{c}\text { Loss mass } 1 \\
(\%)\end{array}$ & $\begin{array}{l}T_{\text {onset2 }} \\
\left({ }^{\circ} \mathbf{C}\right)\end{array}$ & $\begin{array}{c}\text { Loss mass } 2 \\
(\%)\end{array}$ & $\begin{array}{l}T_{\max 2} \\
\left({ }^{\circ} \mathrm{C}\right)\end{array}$ & $\begin{array}{l}T_{\text {onset3 }} \\
\left({ }^{\circ} \mathrm{C}\right)\end{array}$ & $\begin{array}{c}\text { Loss mass } 3 \\
(\%)\end{array}$ & $\begin{array}{l}T_{\max 3} \\
\left({ }^{\circ} \mathrm{C}\right)\end{array}$ & Residue (\%) \\
\hline $\mathrm{BC}$ & 5 & 284 & 64 & 301 & 475 & 30 & 491 & 1 \\
\hline $\mathrm{Ag} 40 \mathrm{O}$ & 6 & 304 & 62 & 325 & 394 & 29 & 390 & 6 \\
\hline $\mathrm{Ag} 20 \mathrm{CN} 2.2 \mathrm{O}$ & 18 & 215 & 35 & 302 & 310 & 25 & 315 & 25 \\
\hline $\mathrm{Ag} 40 \mathrm{CN} 2.2 \mathrm{O}$ & 6 & 281 & 4 & 375 & 381 & 39 & 378 & 11 \\
\hline $\mathrm{Ag} 20 \mathrm{CN} 1.1 \mathrm{O}$ & 8 & 236 & 37 & 323 & 328 & 38 & 332 & 19 \\
\hline $\mathrm{Ag} 40 \mathrm{CN} 1.1 \mathrm{O}$ & 9 & 239 & 48 & 332 & 334 & 28 & 339 & 18 \\
\hline $\mathrm{Ag} 40 \mathrm{~A}$ & 5 & 305 & 58 & 331 & 402 & 35 & 398 & 4 \\
\hline $\mathrm{Ag} 20 \mathrm{CN} 2.2 \mathrm{~A}$ & 15 & 225 & 37 & 308 & 314 & 36 & 310 & 14 \\
\hline $\mathrm{Ag} 40 \mathrm{CN} 2.2 \mathrm{~A}$ & 7 & 295 & 48 & 332 & 388 & 36 & 404 & 7 \\
\hline Ag20CN1.1A & 8 & 254 & 49 & 358 & 362 & 32 & 360 & 15 \\
\hline $\mathrm{Ag} 40 \mathrm{CN} 1.1 \mathrm{~A}$ & 6 & 258 & 50 & 337 & 345 & 31 & 339 & 14 \\
\hline
\end{tabular}

BC membrane (magnification of 10,000x). As observed, the neat $\mathrm{BC}$ presents a dense network of nanofibrils organized in a random arrangement, forming a highly porous structure that allows a high liquid retention. Similar microstructure was reported in the literature by Fischer et al. ${ }^{11}$ and Godinho et al. ${ }^{20}$. The diameter of the fibrils of the neat BC membrane, measured with the ImageJ software, is between 40 and $96 \mathrm{~nm}$. Yan et al. ${ }^{21}$ produced BC membranes from Komagataeibacter hanseni with fibrils in the same size range. Nevertheless, the nanofibers showed a high aspect ratio and, consequently, a fibrils network of $\mathrm{BC}$ with different morphological characteristics.

SEM images of the functionalized BC membranes oventreated are shown in Figure 8. From the micrographies, it is not possible to observe the fibrils, since the oven treatment collapsed the pores, and the membranes presented a highdensity surface. The micrography of the Ag40O sample clearly shows that the AgNPs (white spots) are well dispersed in the $\mathrm{BC}$ membrane. However, although it is not possible to observe the particles in the micrographs of the oventreated samples containing $\mathrm{AgNPs}$ and $\mathrm{Ce}\left(\mathrm{NO}_{3}\right)_{3}$, these were confirmed by EDS, which detected the presence of $\mathrm{Ce}$ and $\mathrm{Ag}$ in all samples.
From SEM images (magnification of 10,000x) of the autoclaved functionalized BC membranes (Fig. 9), it is noticeable that the fibrillar structure was preserved in all the membranes. However, according to the data listed in Table 3, there was an increase in the fibrils diameter with the incorporation of AgNPs, although mainly when $\mathrm{Ce}\left(\mathrm{NO}_{3}\right)_{3}$ was used. These results suggest that fibrils might be coated by the compounds functionalized in the membranes. Fischer et al. ${ }^{11}$ also observed a coating of BC fibrils by the incorporation of such substances. EDS analysis of sample Ag40CN2.2A (Fig 9) demonstrated that the incorporation of AgNPs and $\mathrm{Ce}\left(\mathrm{NO}_{3}\right)_{3}$ were higher in the autoclaved $\mathrm{BC}$ membranes than those submitted to the thermal treatment in the oven. Such findings are evidences that the antibacterial compounds were incorporated in the $\mathrm{BC}$ membranes. Shiny regions are observed on the fibrils surface in the micrographs of the membranes containing $\mathrm{AgNPs}$ and $\mathrm{Ce}\left(\mathrm{NO}_{3}\right)_{3}$, and might be assigned to the presence of the metallic compounds used to functionalize the membranes. Barud et al. ${ }^{22}$ also observed the presence of shiny points onto the surface of BC fibrils, and assigned them to the presence of AgNPs obtained from the hydrolytic decomposition of silver complexes with triethanolamine. 


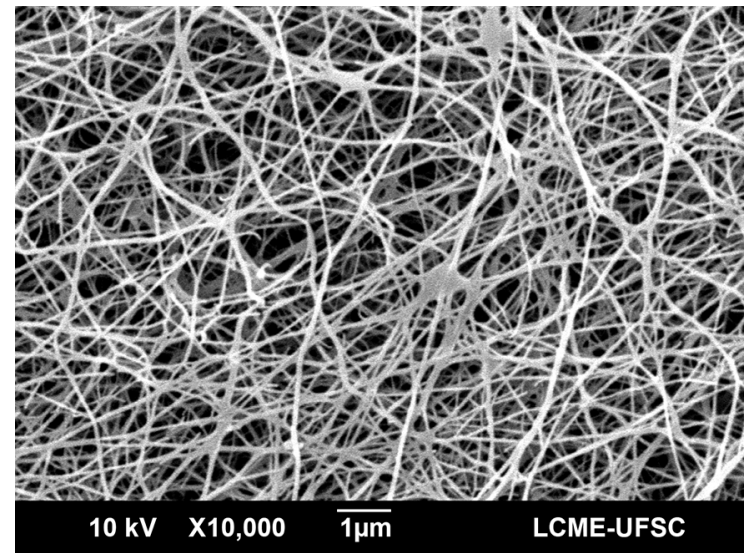

Figure 7. Micrography obtained by scanning electron microscopy of the upper side of neat $\mathrm{BC}$ membrane.

\subsubsection{Wide-angle X-ray diffractometry $(X R D)$}

In the XRD pattern of neat and functionalized $\mathrm{BC}$ membranes (Figure 10) this was evidenced by crystalline peaks at diffraction angles at $2 \theta=14.55^{\circ}(101), 16.88^{\circ}(101)$ and $22.73^{\circ}(002)$, all typical of Cellulose $\mathrm{I}^{23}$

The different concentrations of AgNPs and $\mathrm{Ce}\left(\mathrm{NO}_{3}\right)_{3}$ with different thermal treatments did not show differences in the reflective angle and spacing " $\mathrm{d}$ " of the typical BC membrane (Table 4). However, the degree of crystallinity (Xc) of the membranes decreased by about $5.4 \%$ with the addition of AgNPs and $\mathrm{Ce}\left(\mathrm{NO}_{3}\right)_{3}$ simultaneously, whereas a slight increase of $\mathrm{Xc}$ was observed for the membranes containing only $\mathrm{Ag}(\mathrm{Ag} 40 \mathrm{O}$ and $\mathrm{Ag} 40 \mathrm{~A})$. The presence of Ag was confirmed by the diffraction peaks at $38.3^{\circ}$ and
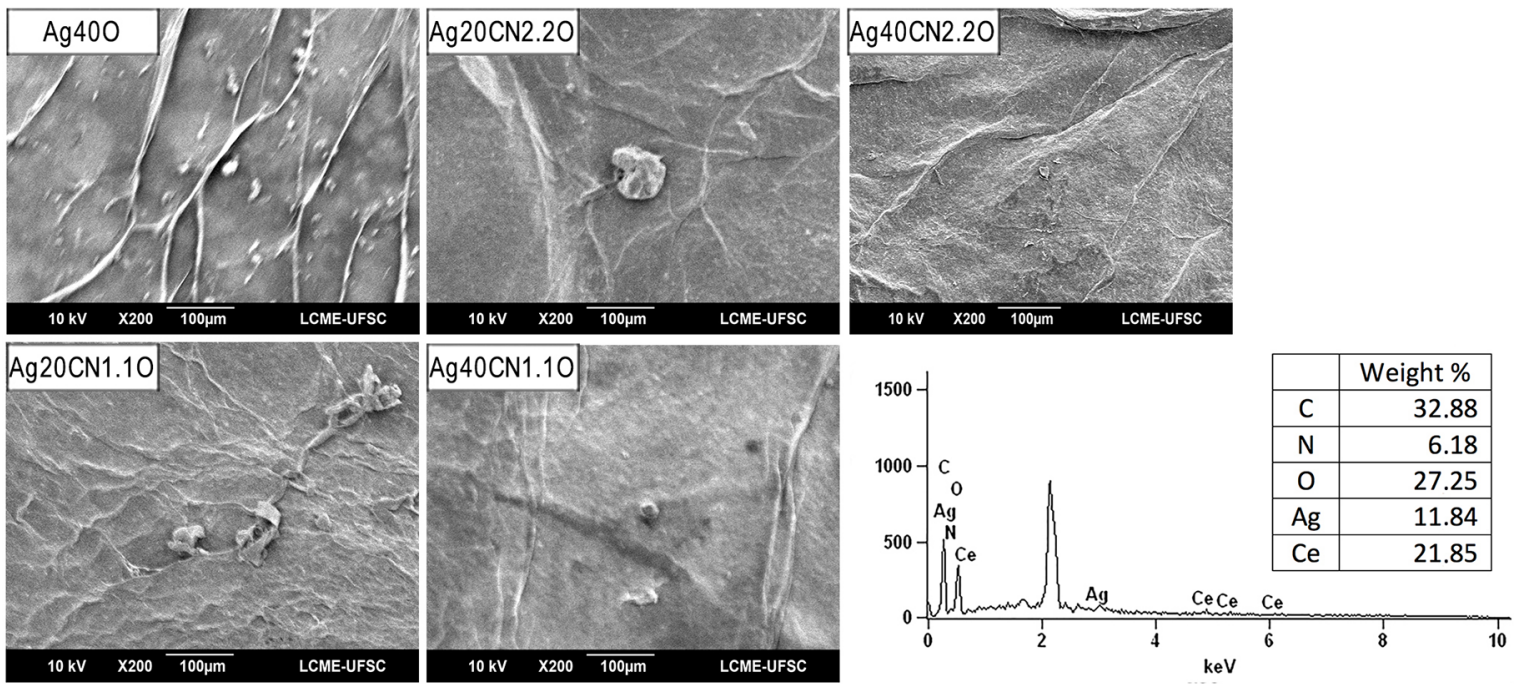

Figure 8. Micrographs obtained by scanning electron microscopy of the upper surface of the functionalized BC membranes submitted to a thermal treatment in oven, and EDS analysis of sample Ag40CN2.1O.
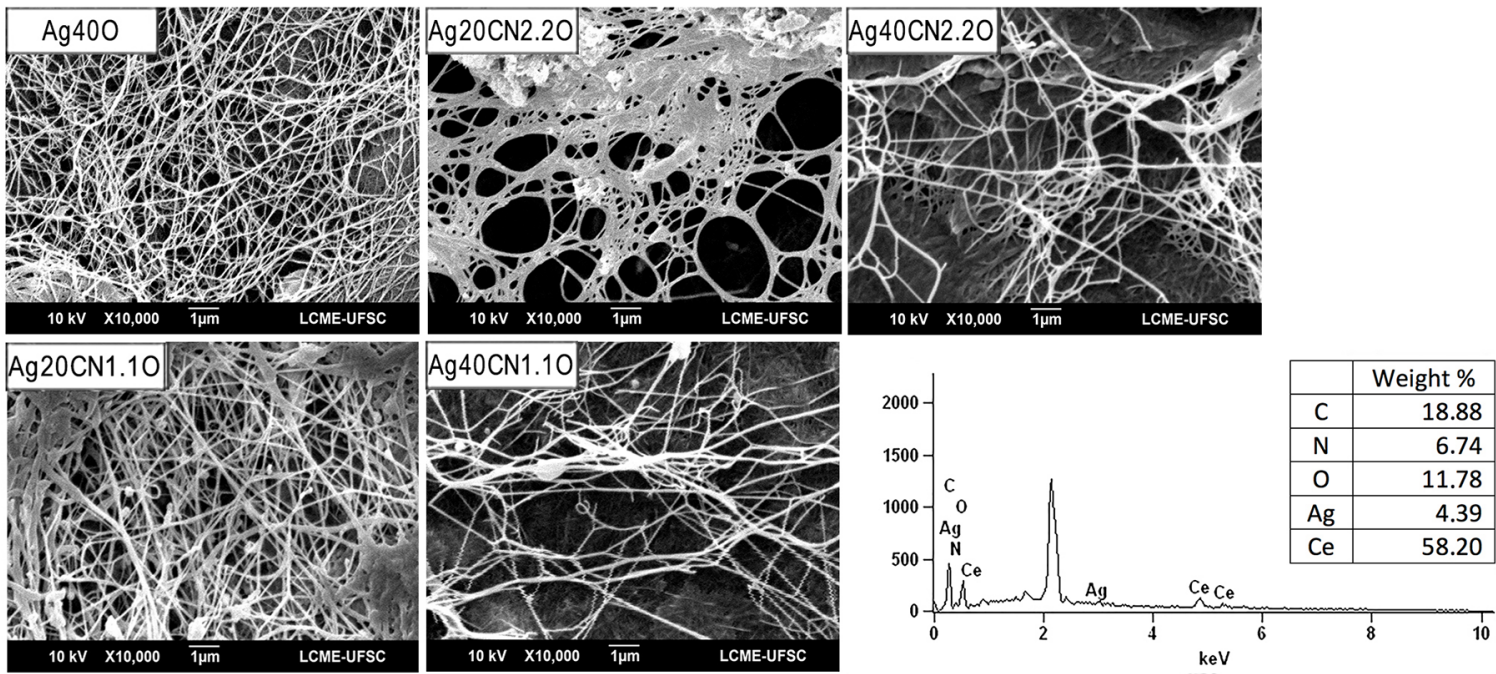

Figure 9. Micrographs obtained by scanning electron microscopy of the upper surface of the functionalized BC membranes submitted to a thermal treatment in autoclave, and EDS analysis of sample Ag40CN2.2A. 
Table 3. Diameter of the fibrils of $\mathrm{BC}$ membranes thermally treated in an autoclave.

\begin{tabular}{lcc}
\hline \multicolumn{3}{c}{ Diameter of the fibrils (nm) } \\
\hline Sample & min & max \\
\hline BC & 40 & 96 \\
Ag40A & 76 & 123 \\
Ag20CN2.2A & 102 & 218 \\
Ag40CN2.2A & 113 & 281 \\
Ag20CN1.1A & 117 & 231 \\
Ag40CN1.1A & 101 & 208 \\
\hline
\end{tabular}

$46.5^{\circ}$ (indicated by the arrows in Fig. 7a) in the membrane containing only AgNPs and thermally treated in an oven (sample Ag40O). These two diffraction peaks at $38.3^{\circ}$ and $46.5^{\circ}$ can be attributed to metallic silver corresponding to the crystallographic planes (111) and (200), respectively ${ }^{24}$. It was not possible to observe the characteristic peaks of AgNPs and $\mathrm{Ce}\left(\mathrm{NO}_{3}\right)_{3}$ in the other membranes due to the low concentration of these substances in the samples.

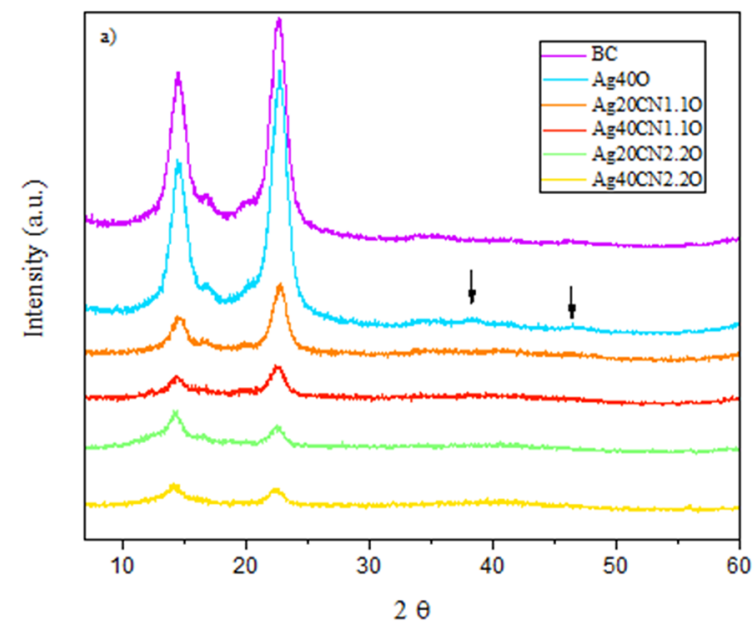

The decrease of crystallinity of functionalized BC membranes can be associated with the cleavage of hydrogen bonds by inclusion of metal elements in the crystallites. This also observed by Casaburi et al. ${ }^{23}$ in your work, when studied $\mathrm{BC}$ samples treated with $\mathrm{NaOH}$.

\subsubsection{Atomic absorption spectroscopy (AAS)}

The results of the Ag concentrations obtained through the AAS technique are presented in Figure 11. The concentrations obtained for the samples Ag40O and Ag40A were higher because these samples contain only AgNPs at the highest concentration. The other samples had Ag levels ranging from 0.02 to $1.37 \mathrm{mg} / \mathrm{g}$, proving that the AgNPs were functionalized into the BC membranes. In a general way, it is possible to conclude that the membranes thermally treated in the autoclave presented more AgNPs than those treated in the oven. These results might be a consequence of the porous structure of the autoclaved membranes, which have a higher surface area available for the attachment of such metallic compound.

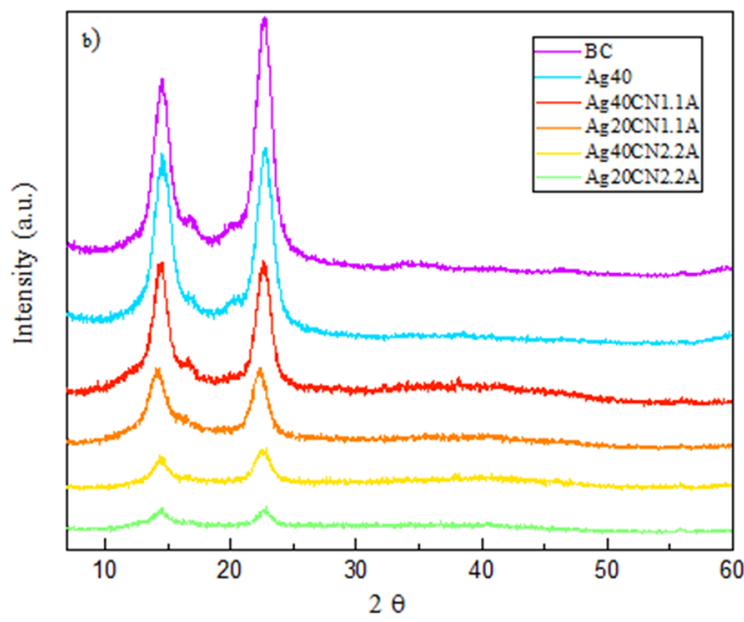

Figure 10. X-ray diffraction patterns of the neat and functionalized BC membranes submitted to different thermal treatments: a) oven; b) autoclave.

Table 4. Data obtained from XRD for the BC membranes submitted to different thermal treatments: crystallinity degree, reflective-angle, d-spacing.

\begin{tabular}{lcccc}
\hline Sample & $\mathbf{X c}(\mathbf{\%})$ & $\mathbf{2 \theta}[\mathbf{d}(\mathbf{1} \mathbf{0})]$ & $\mathbf{2 \theta}[\mathbf{d}(\mathbf{1} \mathbf{0} 1)]$ & $\mathbf{2 \theta}[\mathbf{d}(\mathbf{0 2 0})]$ \\
$\mathrm{BC}$ & 61.42 & $14.60^{\circ}(6.08)$ & $16.88^{\circ}(5.25)$ & $22.73^{\circ}(3.91)$ \\
$\mathrm{Ag} 40 \mathrm{O}$ & 62.84 & $14.50^{\circ}(6.10)$ & $16.78^{\circ}(5.27)$ & $22.76^{\circ}(3.90)$ \\
$\mathrm{Ag} 20 \mathrm{CN} 2.2 \mathrm{O}$ & 55.13 & $14.20^{\circ}(6.22)$ & $16.67^{\circ}(5.31)$ & $22.60^{\circ}(3.93)$ \\
$\mathrm{Ag} 40 \mathrm{CN} 2.2 \mathrm{O}$ & 55.02 & $14.18^{\circ}(6.23)$ & $16.79^{\circ}(5.28)$ & $22.64^{\circ}(3.92)$ \\
$\mathrm{Ag} 20 \mathrm{CN} 1.1 \mathrm{O}$ & 56.34 & $14.42^{\circ}(6.13)$ & $16.85^{\circ}(5.25)$ & $22.86^{\circ}(3.88)$ \\
$\mathrm{Ag} 40 \mathrm{CN} 1.1 \mathrm{O}$ & 55.19 & $14.32^{\circ}(6.17)$ & $16.79^{\circ}(5.27)$ & $22.76^{\circ}(3.90)$ \\
$\mathrm{Ag} 40 \mathrm{~A}$ & 62.06 & $14.50^{\circ}(6.10)$ & $16.66^{\circ}(5.31)$ & $22.80^{\circ}(3.89)$ \\
$\mathrm{Ag} 20 \mathrm{CN} 2.2 \mathrm{~A}$ & 55.90 & $14.59^{\circ}(6.06)$ & $16.61^{\circ}(5.33)$ & $22.80^{\circ}(3.89)$ \\
$\mathrm{Ag} 40 \mathrm{CN} 2.2 \mathrm{~A}$ & 56.18 & $14.28^{\circ}(6.19)$ & $16.67^{\circ}(5.31)$ & $22.51^{\circ}(3.94)$ \\
$\mathrm{Ag} 20 \mathrm{CN} 1.1 \mathrm{~A}$ & 57.19 & $14.32^{\circ}(6.17)$ & $16.31^{\circ}(5.43)$ & $22.34^{\circ}(3.97)$ \\
$\mathrm{Ag} 40 \mathrm{CN} 1.1 \mathrm{~A}$ & 57.37 & $14.57^{\circ}(6.07)$ & $16.73^{\circ}(5.29)$ & $22.53^{\circ}(3.94)$ \\
\hline
\end{tabular}




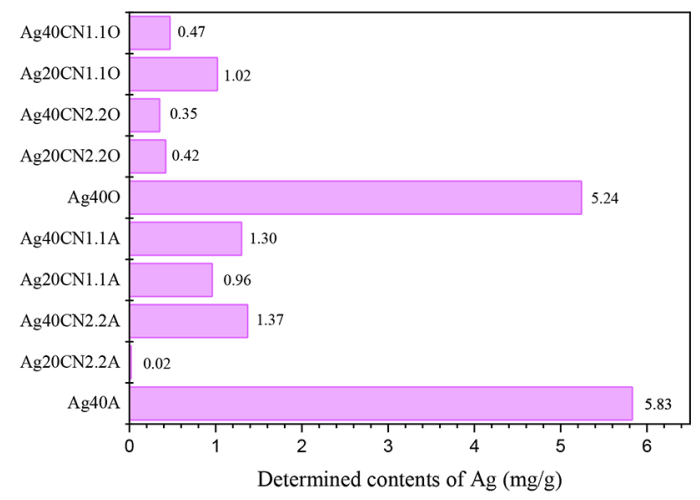

Figure 11. Values of Ag concentrations obtained by AAS on the functionalized $\mathrm{BC}$ membranes.

\subsubsection{Antibacterial activity}

Figure 12 shows the antibacterial activity of the $\mathrm{BC}$ membranes thermally treated in the autoclave and oven in the presence of different concentrations of AgNPs and $\mathrm{Ce}\left(\mathrm{NO}_{3}\right)_{3}$, against the Gram-positive Staphylococcus aureus and Gram-negative bacteria Pseudomonas aeruginosa.
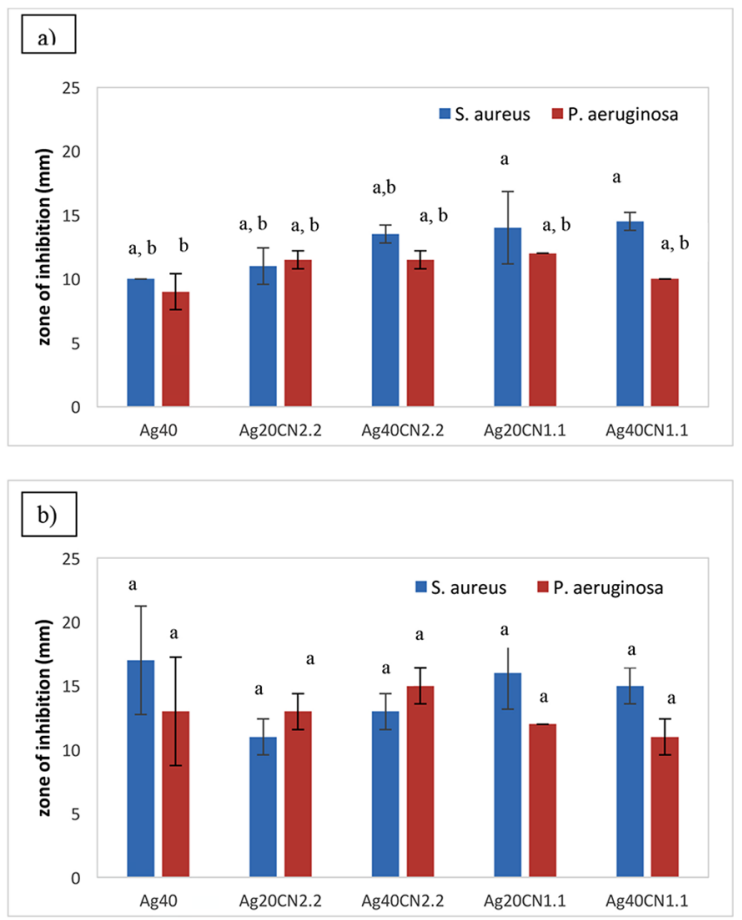

Figure 12. Antibacterial activity of the $\mathrm{CB}$ membranes thermally treated in the autoclave (a) and oven (b) in the presence of different concentrations of AgNPs and $\mathrm{Ce}(\mathrm{NO} 3) 3$, against the Gram-positive Staphylococcus aureus and Gram-negative bacteria Pseudomonas aeruginosa. *Averages that do not share a letter are significantly different.
It was found that there was no significant difference between treatments with $\mathrm{AgNPs}$ and $\mathrm{Ce}\left(\mathrm{NO}_{3}\right)_{3}$ in oven for both microorganisms. However, when the effect of autoclaving treatment on the different organisms tested was evaluated, a significant difference was observed for the different treatments.

The largest inhibition was observed against the bacterium Staphylococcus aureus (Gram-positive) regardless of the thermal treatment. Some authors report that the antibacterial action of AgNPs against Staphylococcus aureus are higher than Gram-negative bacteria ${ }^{25}$. Generally, Gram-negative bacteria are more resistant to antibacterial agents than Gram-positive bacteria due to the complexity of the cell membrane of Gram-negative, which hinders the entry and, consequently, the diffusion of the AgNPs into these microorganisms ${ }^{26}$. Based on studies with individual strains from different cultures, Tomacheski et al. ${ }^{27}$ reported that $S$. aureus is more resistant to AgNPs in comparison to to $E$. coli. In this way, the authors showed that the bactericidal efficiency of the nanoparticles does not depend only on the structure of the bacterial membrane. Therefore, it is not possible to generalize the antibacterial effect of AgNPs based on results of only one strain, since different bacteria exhibit different sensitivities as a function of the structures attached to the cell wall. However, some mechanisms of toxicity are suggested: a) the contribution of free silver ions followed by disruption of ATP production and DNA replication (AgNPs act on the phosphate of DNA molecules resulting in the inactivation of their replication); b) formation of oxygen reactive species by the ions and AgNPs. These molecules react with the sulfhydryl - SH groups of the cell wall to form R-S-S-R blocking respiration, and causing cell death; c) direct damage of the cell membrane by AgNPs, affecting the permeability of the membrane ${ }^{27}$.

The membrane thermally treated in the oven and containing only AgNPs showed the largest inhibition zone (13 $\mathrm{mm}$ and $17 \mathrm{~mm}$ for $P$. aeruginosa and $S$. aureus, respectively) and, consequently, the highest antibacterial efficiency. This behavior might be explained in terms of the microstructure of such membranes. The sample Ag40 (oven) presented a collapsed fibrillar structure, while sample Ag40 (autoclave) formed a porous fibrillar microstructure. So, the nanostructures incorporated in sample Ag40 (oven) might be concentrated on the surface of the membranes, whereas in sample Ag40 (autoclave), the nanostructures are supposed to be incorporated inside the porous of the membrane as well. In this situation, the diffusion of the nanoparticles toward the bacteria media from the autoclaved sample might be slower than from the sample treated in the oven. The fact that the membranes presented antibacterial activity is an evidence of the presence of AgNP and $\mathrm{Ce}\left(\mathrm{NO}_{3}\right)_{3}$ in the samples. 


\subsubsection{Cytotoxicity}

A preliminary cytotoxicity assay is one of the most important evaluations of the biological properties of the biomaterials prior to in vivo assessment ${ }^{28}$. According to the ISO $10993-5^{29}$, if the cell viability is greater than $70 \%$ of the control group, then the material is considered as noncytotoxic. In the cytotoxicity assay performed in this work (Figure 13), it was possible to observe that $\mathrm{Ag} 40 \mathrm{~A}$ and $\mathrm{Ag} 40 \mathrm{O}$ were the samples that presented the best effect on cell viability, revealing a similar behavior regardless the thermal treatment. For these membranes, the cell viability was maintained during the first 3 days of the test. However, the functionalized BC membranes with AgNPs e Ce $\left(\mathrm{NO}_{3}\right)_{3}$ presented a negative effect over the cell viability over the 3 days of evaluation. These findings suggest that $\mathrm{Ce}\left(\mathrm{NO}_{3}\right)_{3}$ is more cytotoxic than AgNPs in the range of concentrations used in the assays. The obtained results indicated that the membranes functionalized with AgNPs could induce a slight decrease in the viability of the cells tested only after 7 days. Although cell viability remained in the range of $70 \%$, considering the standard deviation for both samples, the statistical analysis showed that this difference is statistically significant in relation to the $\mathrm{BC}$ standard. Zhang et al. ${ }^{30}$ explain that the reason for this slight cytotoxicity may be related to the transport of AgNPs into the cell via endocytosis. The AgNPs can be found in the mitochondria and in the nucleus, but their cytotoxic effect depends on the size and their surface modification. Ramenzoni et al. ${ }^{31}$ investigated the influence of cerium chloride on fibroblast cells at different concentrations of cerium and demonstrated a positive response when fibroblast cells were used. Nevertheless, the authors concluded that this effect depends on concentration, time exposure, and cell culture. They emphasized that different cell types may also react differently when exposed to cerium, exhibiting various effects of cytotoxicity. Therefore, the implementation of topical application of cerium to accelerate wound healing merits further investigation. Correlating the data obtained from the $\mathrm{BC}$ microstructure, cell viability and antibacterial activity, the $\mathrm{BC}$ membranes that stood out were those autoclaved and prepared with only AgNPs (Ag40A) and prepared with $20 \mathrm{ppm}$ of $\mathrm{AgNP}$ and $1.1 \%$ of $\mathrm{Ce}\left(\mathrm{NO}_{3}\right)_{3}$ (sample Ag20CN1.1A). These two membrane compositions might be recommended to be used as wound dressing, since they showed good porosity, good antibacterial activity and adequate cell viability on the first day of analysis.

\section{Conclusions}

Based on the characterizations performed for the membranes with different formulations, it can be concluded that the autoclaved samples $\mathrm{Ag} 40$ and $\mathrm{Ag} 20 \mathrm{CN} 1.1$ are the most promising for application in the treatment of burnt skin. The BC membranes thermally treated in the autoclave exhibited a porosity higher than those treated in the oven. This characteristic allows a better gas exchange at the wound site, and good rehydration capacity, which are factors considered extremelly important, since the dressings should be rehydrated prior to application over the skin to improve adhesion. The autoclaved membranes prepared with the solution containing only $40 \mathrm{ppm}$ of AgNPs and with 20 ppm and $1.1 \%$ of $\mathrm{Ce}\left(\mathrm{NO}_{3}\right)_{3} 1.1 \%(\mathrm{Ag} 20 \mathrm{CN} 1.1)$ showed the highest antibacterial efficacy. Nevertheless, for the sample Ag20CN1.1, it is necessary to change the dressing constantly due to the rapid lowering of cell viability. On the other hand, the autoclaved membrane containing only AgNPs is more advantageous to be used in the treatment of burnt skins, since there is no need for constant dressing change.

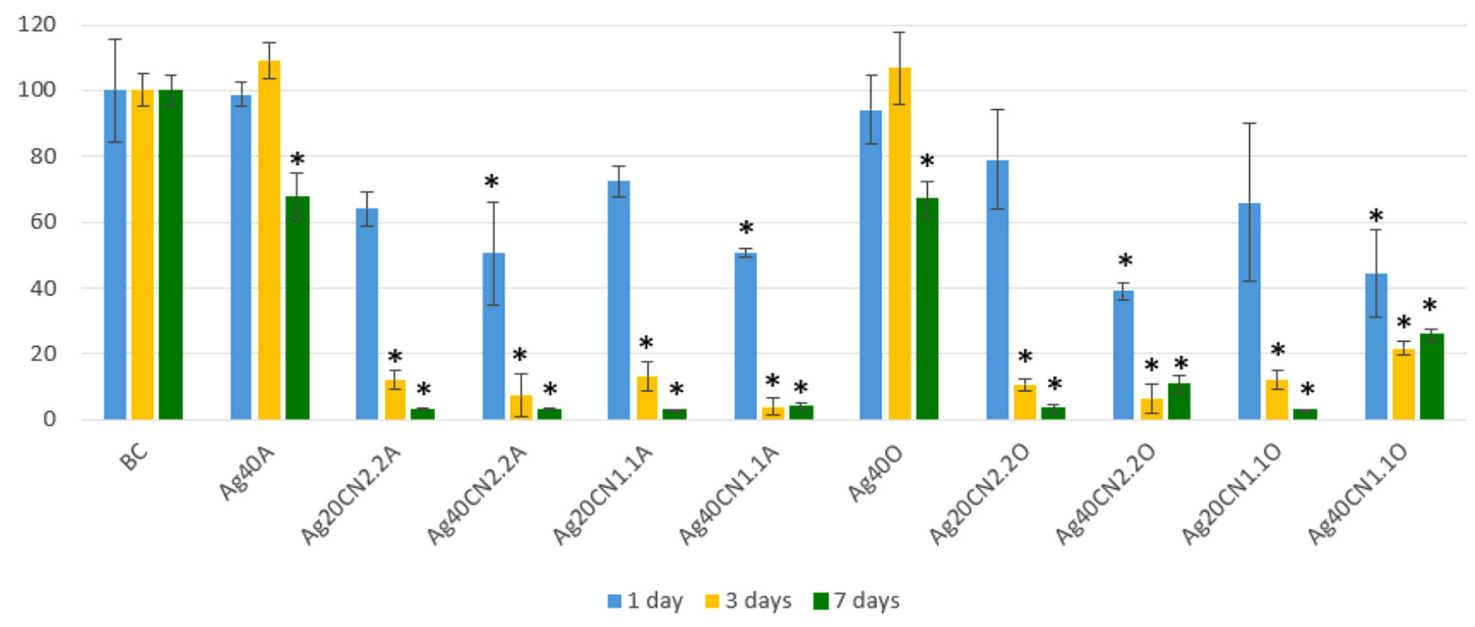

Figure 13. Graph of \% of cell viability over time for the samples thermally treated in the oven and in the autoclave. *significant differences with respect to the $\mathrm{BC}$ group (control) on the respective days of exposure (or incubation). 


\section{Acknowledgment}

The authors are grateful to Univille for their financial support, to the Government of the State of Santa Catarina for the scholarship of Scientific Initiation of art. 170, to the Central Laboratory of Electronic Microscopy (LCME) of UFSC for the SEM analysis, and to the Structural Characterization Laboratory (LCE) of UFSCar for performing TEM and XRD analyses.

\section{References}

1. Schneider JC, Chen L, Simko LC, Warren KN, Nguyen BP, Thorpe CR, et al. Challenges to the Standardization of Burn Data Collection: A Call for Common Data Elements for Burn Care. Journal of Burn Care and Research . 2017;39(2):201-208.

2. Ramos G, Cornistein W, Cerino, GT, Nacif G. Systemic antimicrobial prophylaxis in burn patients: systematic review. Journal of Hospital Infection. 2017;97:105-114.

3. Wu J, Yin N, Chen S, Weibel DB, Wang H. Simultaneous $3 \mathrm{D}$ cell distribution and bioactivity enhancement of bacterial cellulose (BC) scaffold for articular cartilage tissue engineering. Cellulose. 2019;26(4):2513-2528.

4. Pitcheth GF, Pirich CL, Sierakowski MR, Woehl MA, Sakakibara $\mathrm{CN}$, Souza $\mathrm{CF}$, et al. Bacterial cellulose in biomedical applications: A review. International Journal of Biological Macromolecules. 2017;104(Pt A):97-106.

5. Lustri WR, Barud HGOB, Barud HS, Peres MFS, Gutierrez J, Tercjak A, et al. Microbial Cellulose - Biosynthesis Mechanisms and Medical Applications. In: Lustri WR, Barud HGOB, Barud HS, Peres MFS, Gutierrez J, Tercjak A, Oliveira Junior OB, Ribeiro SJL, editors. Cellulose - Fundamental Aspects and Current Trends. London: InTechOpen; 2015. p. 133-156.

6. Napavichayanun S, Yamdech R, Aramwit P. Development of bacterial cellulose incorporating silk sericin, polyhexamethylene biguanide, and glycerin with enhanced physical properties and antibacterial activities for wound dressing application. International Journal of Polymeric Materials and Polymeric Biomaterials. 2017;67(2):61-67.

7. Xie Y, Yue L, Zheng Y, Zhao L, Liang C, He W, et al. The antibacterial stability of poly(dopamine) in-situ reduction and chelation nano-Ag based on bacterial cellulose network template. Applied Surface Science. 2019;491:383-394.

8. Shao W, Liu H, Liu X, Sun H, Wang S, Zhang R. pH-responsive release behavior and anti-bacterial activity of bacterial cellulosesilver nanocomposites. International Journal of Biological Macromolecules. 2015;76:209-217.

9. Li Z, Wang L, Chen S, Feng C, Chen S, Yin N, et al. Facilely green synthesis of silver nanoparticles into bacterial cellulose. Cellulose. 2015;22(1):373-383

10. Boeckx W, Blondeel PN, Vandersteen K, Wolf-Peeters C, Schmitz A. Effect of cerium nitrate-silver sulphadiazine on deep dermal burns: a histological hypothesis. Burns. 1992;18(6):456-62.
11. Fischer MR, Garcia MCF, Nogueira AL, Porto LM, Schneider ALDS, Pezzin APT. Biossíntese e caracterização de nanocelulose bacteriana para engenharia de tecidos. Matéria (Rio de Janeiro). 2017;22(Suppl 1):e11934.

12. Fang L, Catchmark JM. Structure characterization of native cellulose during dehydration and rehydratio. Cellulose. 2014;21(6):3951-3963.

13. Foster EJ, Moon RJ, Agarwal UP, Bortner MJ, Bras J, CamareroEspinosa S, et al. Current characterization methods for cellulose nanomaterials. Chemical Society Reviews. 2018;47(8):2609-79.

14. Bauer AW, Kirby WMM, Sherris JC, Turck M. Antibiotic susceptibility testing by a standardized single disk method. American Journal of Clinical Pathology. 1966;45(4):493-496.

15. Tabaii MJ, Emtiazi G. Comparison of Bacterial Cellulose Production among Different Strains and Fermented Media. Applied Food Biotechnology. 2016;3(1):35-41.

16. Wan H, Williams RL, Doherty PJ, Williams DF. The cytotoxicity evaluation of Kevlar and silicon carbide by MTT assay. Journal of Materials Science: Materials in Medicine. 1994:5(6-7):441445.

17. Molina MA, Rivarola CR, Barbero C. Study on partition and release of molecules in superabsorbent thermosensitive nanocomposites. Polymer. 2012;53(2):445-453.

18. Mohammadkazemi F, Azin M, Ashori A. Production of bacterial cellulose using different carbon sources and culture media. Carbohydrate Polymers. 2015;117:518-523.

19. Araújo Júnior AM, Braido G, Saska S, Barud HS, Franchi LP, Assunção RMN, et al. Regenerated cellulose scaffolds: Preparation, characterization and toxicological evaluation. Carbohydrate Polymers. 2016;136:892-898.

20. Godinho JF, Berti FV, Müller D, Rambo CR, Porto LM. Incorporation of Aloe vera extracts into nanocellulose during biosynthesis. Cellulose. 2015;23(1):545-55.

21. Yan H, Chen X, Song H, Li J, Feng Y, Shi Z, et al. Synthesis of bacterial cellulose and bacterial cellulose nanocrystals for their applications in the stabilization of olive oil pickering emulsion. Food Hydrocolloids. 2017;72:127-135.

22. Barud HS, Barrios C, Regiani T, Marques RFC, Verelst M, Dexpert-Ghys J, et al. Self-supported silver nanoparticles containing bacterial cellulose membranes. Materials Science and Engineering: C. 2008;28(4):515-518.

23. Casaburi A, Rojo UM, Cerrutti P, Vazquez A, Foresti ML. Carboxymethyl cellulose with tailored degree of substitution obtained from bacterial cellulose. Food Hydrocolloids. 2018;75:147-156.

24. Nogueira AL, Machado RAF, Souza AZ, Franco CV, Dutra GB. Influence of Process Parameters and Scalability of the SemiBatch Production of Functionalized Silver Nanoparticles. The Canadian Journal of Chemical Engineering. 2016;94(8):14721485 .

25. Bal KE, Bal Y, Cote G, Chagnes A. Morphology and antimicrobial properties of Luffa cylindrica fibers/chitosan biomaterial as micro-reservoirs for silver delivery. Materials Letters. 2012;79:238-241 
26. Duràn N, Duràn $M$, Jesus $M B$, Seabra AB, Fávaro WJ, Nakazato G. Silver nanoparticles: A new view on mechanistic aspects on antimicrobial activity. Nanomedicine. 2016;12(3):789-799.

27. Tomacheski D, Pittol M, Ribeiro VF, Santana MCR. Efficiency of silver-based antibacterial additives and its influence in thermoplastic elastomers. Journal of Applied Polymer Science. 2016;133(37):43956.

28. Wei CK, Ding SJ. Dual-functional bone implants with antibacterial ability and osteogenic activity. Journal of Materials Chemistry: B. 2017;5(10):1943-1953.
29. International Standards Organization (ISO). ISO 10993-5:2009 - Biological evaluation of medical devices - Part 5: tests for in vitro cytotoxicity. Geneva: ISO; 2009.

30. Zhang T, Wang L, Chen Q, Chen C. Cytotoxic Potential of Silver Nanoparticles. Yonsei Medical Journal. 2014;55(2):283-91.

31. Ramenzoni LL, Weber EF, Attin T, Schmidlin PR. Cerium Chloride Application Promotes Wound Healing and Cell Proliferation in Human Foreskin Fibroblasts. Materials (Basel). 2017;10(6):573-582. 